\title{
Life Cycle Theory of Dividend: A Review Literature
}

\author{
Sri Hasnawati ${ }^{1}$ \\ \{sri.hasna2015@gmail.com $\left.{ }^{1}\right\}$
}

Faculty of Economics and Business, Universitas Lampung, Lampung-Indonesia ${ }^{1}$

\begin{abstract}
The purpose of the paper is to examine the relationship between dividend policy of the company and the life cycle theory. According to the life cycle theory, the company will pay dividend in the third stage, namely the maturity stage. In the early stage, the company has investment opportunities with high profit potential so that it requires large funds. As a result, dividend payments will be delayed. However, dividend payments remain a matter of debate today because dividend payments will be associated with company value. The theory of dividend policy states that paying dividends will increase firm value, but several research results show that dividend payments are not related to firm value.
\end{abstract}

Keywords: Dividend, Life cycle theory, Review

\section{Introduction}

Dividend policy is an important financial decision but is always a matter of debate. Some theories say that dividends must be paid because it can increase the value of the company. This theory is referred to as the relevant dividend theory. Another opinion says that dividends are irrelevant because they are unable to increase the value of the company when it is paid or not. This dilemma arises because of theoretical doubts about the importance of dividend policy in determining firm value. [1] found that companies with high levels of profitability and low growth tended to pay dividends, while companies with low profits/high growth tended to maintain the profits.

The policy of dividend payment must be considered carefully because they are closely related to other financial policies such as investment and capital structure. Once dividend payments are made, internal sources of financing will be reduced, and external financing will be the choice. The results of the empirical research indicate a variety of factors that affect dividends. Although it still becomes a debate until the present time, empirically, dividend theory is influenced by factors such as income stability, historical dividends, current income, expected income, stock prices, liquidity, asymmetric information, investment plans, shareholder welfare, leverage, capital structure and many more.

Companies that are experiencing growth and wishing high profitability will need a substantial fund to finance their investment. Thus, there is a possibility that dividend payments can be postponed. In addition to the reason for investing, dividend distribution is still given because it can be used as a monitoring tool as well as bonding for management and reduce the agency problems, [2]. Dividends can make shareholders have secure income and can reduce agency cost of equity due to perquisite actions taken by management on the company's cash flow. In line with the decrease in monitoring costs, shareholder trust is increasingly positive because management policies may give benefit to the shareholders.

The theory of dividend policy introduced by Modigliani \& Miller about relevant and irrelevant dividends. Furthermore, [3] established a smoothing dividend model, which implies that companies decide their dividend payment policy based on long-term income targets. This theory is based on the assumption that investors prefer stable and current dividends to the unstable ones. It may imply that even if income increases, management will not decide on an appropriate dividend increase until the increase in income can be considered stable in the long run. Conversely, management tends to set current year's dividend payments that reflect the previous year's level of payments. Furthermore [3] explained that changes in dividends will affect investors' views on future earnings prospects, which is known as signal theory. These changes are used to convey the information about the condition of the company in the future by the company itself. 
Baker and Wurgler [4] introduced the dividend catering theory. This theory is based on the idea that investors demand dividends. Dividend payments are the service from the manager for the investors. According to the theory, the decision to pay dividends is based on the assumptions about the premium that investors pay on shares that pay dividends. Furthermore, [5] developed a theory, arguing that it is important to consider how much the dividend rate changes, and not only if the company pays dividends or not. They found that there is a positive relationship between dividend premiums and changes in dividend rates, as well as the size of the changes.

The relationship between dividend payments and the company's life cycle has been the subject of interesting debate both in theoretically and empirical research. [6] stated that dividends tend to be paid by companies that are mature and established. It reflects a financial life cycle in which startups face relatively abundant investment opportunities with limited resources. Unlike the companies that have grown up. Mature companies are a better condition to pay dividends, because they have higher profitability and fewer attractive investment opportunities.

\subsection{Research Issue}

The theory of dividend policy is generally associated with the efforts to increase the value and financing of the company. The question that is often raised is whether to pay high dividends or vice versa, stock dividends or repurchases. On the other hand, company earnings are important as the main source in determining dividend payments. However, in its development, dividend policy is not only determined by how much and what will be done. Moreover, it depends on where the company is in its life cycle. In the early stages, the company generally has high growth with large revenue and lots of investment opportunities. Meanwhile, in a mature situation, companies generally have high free cash flow and reduced investment opportunities. The stages of the company's life cycle will determine how the dividend policy will be carried out. Theoretically, in the early stages of the company's life cycle, dividends are not distributed because the company needs funds for investment. In contrast to the adult stage, there is high free cash flow and small investment opportunities, the company should pay dividends. This issue is interesting to be studied further, whether or not the dividend policy follows the company's life cycle.

\subsection{Literature Review}

Mueller [7] established a firm life cycle theory and developed a hypothesis from this theory regarding dividend payments. This theory suggests that a company's dividend policy should depend on where it is in its life cycle. Companies at the initial stage must reinvest the generated income to realize investment opportunities and reduce uncertainty. It is in line with what shareholders want, because shareholders wish to possess shares in companies that can generate profits with competitive products and are profitable in the long term. As markets saturate and competition increases, profitable investment opportunities will decrease. At this point, big companies at the maturity stage tend to have large cash flows, from the results of their investments. Therefore, a company at the maturity stage must pay dividends to its shareholders [7].

In the early phases of the company's life cycle, agency problems may not exist, because management incentives align with shareholder interests. It happens because of many profitable investment opportunities, high returns and growth rates [7]. In addition, the internally generated income tends to be low to take all existing investment opportunities. Therefore, companies must get financing from external markets, which means that management activities will be monitored [8]. Furthermore, [7] stated that managers of small, growing companies tend to possess a large number of shares in the company, thereby aligning their interests with other shareholders.

As the company reaches the maturity phase, agency problems are more likely to occur. Still according to [7], in this stage of the life cycle, company management had to start distributing income to shareholders. At the same time, all profitable investment opportunities ceased to exist. Agency problems occur when management continues to invest in unprofitable investments. Investments are made only to keep companies from growing further, thereby increasing their personal wealth and power at the expense of shareholder welfare. 
Furthermore, this theory predicts that large companies in the maturity phase, have to pay more dividends than small companies [1], [7].

DeAngelo [6] added Mueller's theory by determining the stage of the company's financial life cycle associated with the amount of retained earnings compared to total equity (RE/TE). It goes on to say, companies with low RE/TE tend to be in the growth stage and dependent on external capital while companies with high RE/TE tend to be more mature with high profit accumulation, thus making them good candidates to pay dividends. Consistent with the previous research, [9] tested the life cycle theory with dividend payout policies in Australia. Empirical evidence strongly supported the dividend life cycle theory. Specifically, they found the evidence that firms which paid larger dividends and gave more profitable dividends, had fewer growth options and higher retained earnings than firms that paid no dividends. In addition, [10] tested the dividend life cycle theory in the Egyptian market. They found that retained earnings on total equity and profitability had a significant positive effect on dividend payments. This provided evidence for the existence of the dividend life cycle theory in Egypt.

Denis \& Osobov (2008) [11] conducted research in six financial markets of developed countries during 1989-2002 on the tendency of companies to pay dividends. They found that dividend payments were associated with firm size, growth opportunities, and profitability. This result was in line with research done by [1]. Furthermore, it was said that in the six countries observed, dividend payments were associated with the ratio of retained earnings to total equity. Companies that paid high dividends when this ratio was high and low and when retained earnings are negative. These results were consistent with the results of a study conducted by [6], they showed that dividends did not decrease over time but were concentrated among the largest and most profitable firms. This finding was consistent with the prediction of life-cycle theory that the distribution of free cash flow is a major determinant of dividend policy. On the other hand, the results was in contrast to [12] which stated that companies tend to increase dividends when moving from a growth phase to a more mature phase. As a growing company matures, its investment opportunities decrease, which in turn leads to an increase in the company's free cash flow. The mature company then pays this free cash flow in the form of a dividend or share buyback. Therefore, an increase in dividends may give signal not only a change in the company's fundamentals but also a commitment by management not to invest too much.

Thanatawee [13] conducted research in Thailand. He found that larger and more profitable companies with higher free cash flow and high retained earnings to equity tended to pay higher dividends. In addition, the evidence suggested that companies with higher growth opportunities, proxied by the market-to-book ratio, tended to pay lower dividend payout ratios. The overall results of this study supported the free cash flow relationship and the lifecycle hypothesis. Furthermore, it was found that financial leverage was positively related to dividend payments. In other words, it can be stated that companies in Thailand depend on debt to pay dividends. This is in contrast to the results of research done by [14] in Indonesia. The results of the study found that public companies in Indonesia followed the life cycle hypothesis in dividend payments. In addition, it was found that there was a tendency for company dividends to decrease from time to time. These findings not only provided relatively new empirical evidence on dividend policy in Indonesia, but also had a potential policy contribution. The policy contribution given was the payment of dividends to shareholders referring to the company's life cycle. Companies should only be required to pay dividends when they reached a certain stage and/or fulfill certain characteristics, and action should only be taken against companies that do not pay dividends even though they could afford it, according to the company's life cycle.

Kouser et. al. [15] examined the impact of the financial crisis in 2008 on dividend payout policy in Karachi, using life cycle determinants. They found that during the financial crisis (2007-2009), companies used a conservative strategy and focused more on maintaining high liquidity rather than distributing dividends. Profitability variables, size and the relationship between investment opportunities and the probability to pay dividends did change significantly due to the financial crisis. Therefore, this study concludes that the company's dividend payment decision depends not only on the company's stage in the life cycle, but also on the company's financial position.

\section{Research Method}


This paper is a scientific literature study that focuses on the life cycle theory of Dividend on the Indonesian stock exchange. Furthermore, the writing materials were obtained from research and scientific journals, both online and in hard copies, and the results show the textbook source as relevant.

\section{Results and Discussion}

Corporate dividend policy is closely related to the agency theory. Shareholders as the funder are entitled to the company return in the form of dividends. But on the other hand, the company also needs funds to increase the company's growth in the future. Agency problems in dividend policy can be related to the company's life cycle. In the growth phase, the company generally will not pay dividends. The reason is because the profit generated will then be used to take every existing investment opportunity in order to increase growth in the future. In this phase, the agency problem can be said to be non-existent because the interests of the company and shareholders are still in line, namely increasing the company's growth. In contrast to the mature phase, the company's growth has started to decline as well as less profitable investment opportunities. As a result, cash is abundant so that it can be used to pay dividends. In this phase, agency problems begin to emerge associated with the use of abundant cash funds. Shareholders still want high growth, but the investment environment is not likely supportive. As a result, management uses cash funds for investments that are less profitable and part of it is used to increase management enjoyment by creating new facilities. However, companies with high managerial and individual ownership do not have the desire to pay dividends compared to companies with low managerial and individual ownership. [16], [17] found that when corporate shareholders are dominated by institutional investors, the company would pay larger dividends.

Various research results related to dividend policy with life cycle theory found that dividend policies in various countries follow the life cycle theory. Besides that, it is also influenced by the economic situation that occurs. Dividend payment in a crisis situation and normal economy will be different but still refers to the phase the company is in. In many studies, dividend policy is only influenced by the company's fundamental factors. The fact usually found in companies that have free cash flow dividend payments are associated with the growth described by the life cycle theory. Consistent with the life cycle hypothesis, [17], [18] found that firms with lower market to bookkeeping ratios had greater returns, cash levels, and capital expenditures and were more likely to pay dividends.

Three factors that influence the decision to pay dividends are mentioned as profitability, investment opportunities, and size, confirming the life cycle theory. Companies that are relatively large and more profitable, are more likely to pay dividends [1], [6], [11]. Firms with high current profitability and low growth rates tend to pay dividends, whereas low-profit firms with high growth firms tend to retain profits. The more real the company's assets are, the less dependent on retained earnings for its growth plans, have more cash to distribute as dividends [19], [20].

\section{Conclusions}

Based on theoretical studies that have been done, dividend payments made by companies generally follow the life cycle theory. However, several studies on dividend payment policies are adjusted to the company's financial condition, size and economic situation. In addition, the dividend policy is also implemented in order to reduce the agency problems.

\section{Acknowledgement}

This paper will be developed into an empirical study that explains the relationship between dividend policy and life cycle theory in Indonesia with other supporting variables. 


\section{References}

[1] E. F. Fama, K. R. French. Disappearing Dividends: Changing Firm Characteristics or Lower Propensity to Pay? J. financ. econ. 2001; no. 60: 3-43.

[2] M. C. Jensen, W. H. Meckling. Theory of the Firm: Managerial Behavior, Agency Costs and Ownership Structure. J. financ. econ. 1976; no. 3: 305-360.

[3] J. Lintner. Distribution of Incomes of Corporations Among Dividends, Retained Earnings, and Taxes. Am. Econ. Rev. 1956; no. 46: 97-113.

[4] M. Baker, J. Wurgler. A Catering Theory of Dividend. J. Finance. 2004; vol. 59: 1125-1165.

[5] W. Li, E. Lie. Dividend changes and catering incentives. J. financ. econ. 2006; vol. 80(2): 293308.

[6] H. DeAngelo, L. DeAngelo, R. Stulz. Dividend Policy and the Earned/Contributed Capital Mix: A Test of the Life-Cycle Theory. J. Financ. Econ.. 2006; vol. 81: 227-254.

[7] D. Mueller. A Life Cycle Theory of the Firm. J. Ind. Econ. 1972; vol. 20, no. 3: 199-219.

[8] H. K. Baker. Dividends and Dividend Policy. John Wiley \& Sons, Inc: 2011.

[9] J. J. Coulton, C. Ruddock. Corporate payout policy in Australia and a test of the life cycle theory. Account. Financ. 2011; vol. 5(1): 381-407.

[10] O. El-Ansary, T. Gomaa. The Life Cycle Theory of Dividends: Evidence from Egypt. Int. Res. J. Financ. Econ. 2012; no. 97: 72-80.

[11] D. Denis, I. Osobov. Why Do Firms Pay Dividends? International Evidence on the Determinants of Dividend Policy. J. financ. econ. 2008; vol. 89: 62-82.

[12] G. Grullon, R. Michaely, B. Swaminathan. Are Dividend Changes a Sign of Firm Maturity?. J. Bus. 2002; no. 75: 387-424.

[13] Y. Thanatawee. Life-Cycle Theory and Free Cash Flow Hypothesis: Evidence from Dividend Policy in Thailand. Int. J. Financ. Res. 2011; vol. 2(2).

[14] L. I. Wardhana, E. Tandelilin, L. I. W. Nuka, J. E. Junarsi. Dividend Policy in Indonesia: A LifeCycle Explanation. 2014; Asian Finance Association (Asian FA) 2014 Conference Paper.

[15] R. Kouser, R. Lugman, A. Yaseen, M. Azeem. Dividend Payout Policy and Financial Crisis: Evidence from the Life Cycle Theory. Pakistan J. Commer. Soc. Sci. 2015; vol. 9(2): 583-597.

[16] T. Afza, H. H. Mirza. Ownership structure and cash flows as determinants of corporate dividend policy in Pakistan. Int. Bus. Res. 2010; vol. 3(3): 210-221.

[17] B. Stacescu. Dividend policy in Switzerland. Financ. Mark. Portf. Manag. 2006; vol. 20: 153-183.

[18] N. L. Fargher, R. A. Weigand. Why firms begin paying dividends: value, growth, and life cycle effects. Dividends and Dividend Policy. 2009; 421-445.

[19] V. Aivazian, L. Booth, S. Clearly. Dividend smoothing and debt ratings. J. Financ. Quant. Anal. 2006; vol. 41(2).

[20] J. Al-Ajmi and A. Hussain. Corporate dividend decisions: evidence from Saudi Arabia. J. Risk Financ. 2011; vol. 12(1): 41-56. 